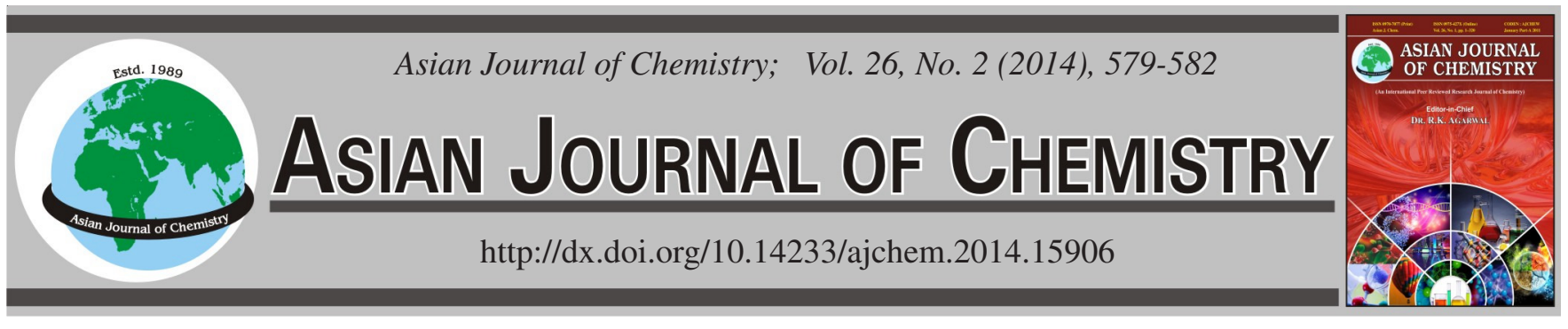

\title{
Urban Wastewater as Hotspot for Antibiotic and Antibiotic Resistant Bacteria Spread into the Aquatic Environment
}

\author{
Maqsood Ahmad ${ }^{1, *}$, Amin U. Khan ${ }^{1}$, Abdul Wahid $^{2}$, Muhammad Farhan ${ }^{1}$, Zahid Ali Butt $^{3}$ and Faroog Ahmad $^{1}$
}

\author{
${ }^{1}$ Sustainable Development Study Centre, Government College University, Lahore, Pakistan \\ ${ }^{2}$ Department of Environmental Sciences, Bahauddin Zakariya University, Multan, Pakistan \\ ${ }^{3}$ Abdul Wali Khan University, Mardan, Pakistan
}

*Corresponding author: Email: maqsood_ahmad92@yahoo.com

Received: 13 June 2013;

Accepted: 2 September 2013;

Published online: 15 January 2014;

AJC-14591

\begin{abstract}
The present study was under taken to investigate the occurrence of ofloxacin in hospital wastewater, municipal wastewater and in river water receiving the sewage; along with the assessment of antibiotic resistant Salmonella typhimurium (S. typhi) in these waters. Transfer of antibiotic resistance between two different strains of bacteria was also studied. Untreated sewage from the three hospitals (Mayo, Services and Jinnah) directly entering into municipal wastewater and ultimately flows into the river Ravi without any prior treatment. The concentration of ofloxacin in wastewater of the three hospitals was ranged between 10.69 to $30.55 \mu \mathrm{g} \mathrm{mL} \mathrm{m}^{-1}$. However, before mixing of the hospital wastewater, concentration of ofloxacin in the three municipal wastewater drains (receiving the wastewater) was ranged between 0.26 to $0.43 \mu \mathrm{g} \mathrm{mL} \mathrm{mL}^{-1}$. Downstream to the hospitals, increase in concentration was observed and concentration was ranged between 0.54 to $1.29 \mu \mathrm{g} \mathrm{mL}^{-1}$. The river water was not contaminated with ofloxacin upstream to the city, while a concentration of the antibiotic downstream to the city was $0.067 \mu \mathrm{g} \mathrm{mL}^{-1}$. All the water samples collected from hospital and municipal wastewater drains were contaminated with S. typhi. It was noted that hospital isolates were more resistant $(50 \%)$ to ofloxacin as compare to municipal wastewater isolates $(16.7 \%)$. No $S$. typhi was detected from the river water before entering first municipal wastewater drain from the city. Downstream to first municipal wastewater drain S. typhi were detected and $33 \%$ of them were resistant to ofloxacin. The bacterial isolates isolated from river water downstream to the city were $100 \%$ resistant to the antibiotic. The results of co-culture of ofloxacin resistant $S$. typhi and ofloxacin sensitive Escherichia coli revealed that the resistant $S$. typhi were able to transfer the antibiotic resistance to another species.
\end{abstract}

Keywords: Ofloxacin, Salmonella typhimurium, Wastewater, Antibiotic resistance.

\section{INTRODUCTION}

Antibiotics belong to fluoroquinolones, macrolides and sulfonamides groups are widely using to treat bacterial infections of humans and animals ${ }^{1}$. Most of the antibiotics cannot be completely metabolized by humans or animals, so excreted to environment through different excretions like urine and feces ${ }^{2}$. Other sources of antibiotics in the environment are Hospital, municipal and industrial wastewaters ${ }^{3}$. Most of antibiotics decomposed when enter into aquatic environment at a certain rate, but they become pseudopersistent due to continuous intake into the environment ${ }^{4}$. In the field of environmental science, antibiotic are new type of pollutants and their impacts on humans and animals are also not well know ${ }^{5}$. Common antibiotics like ciplofloxacin, norfloxacin and ofloxacin have been found in hospital wastewater ${ }^{6}$, municipal wastewater ${ }^{7}$, river sediments and water ${ }^{8}$. Antibiotic pollution is now become a serious problem for many rivers and oceans ${ }^{4}$.
The wastewaters also carry human and animal pathogenic bacteria to water environment and many of them carrying antibiotic resistant genes. Once bacteria with the resistant genes enter into the environment, they become able to spread the genes into water and soil bacteria ${ }^{9}$. Water environment not only responsible for the dissemination of antibiotic resistant bacteria among humans and animals through drinking water and food, but also facilitate the resistant bacteria to transfer the resistant genes to nonpathogenic natural bacterial ecosystem. In this way, the nonpathogenic bacteria could be act as reservoir of antibiotic resistant genes ${ }^{10}$. This is the reason that antibiotic and antibiotic resistant genes becoming a global health issue. The problem can only solve by developing specific treatment procedures for the removal of antibiotics and pathogenic bacteria from hospital and municipal wastewaters, because conventional wastewater treatment plants are not able to completely remove the pollutants ${ }^{9,11}$. The problem is more severe in developing countries because no wastewater treatment facility is available in most of the cases ${ }^{6}$. 
TABLE-1

CONCENTRATION $\left(\mu \mathrm{g} \mathrm{mL}^{-1}\right)$ OFLOXACIN of IN HOSPITAL WASTE WATER, MUNICIPAL WASTE WATER AND IN RIVER WATER

\begin{tabular}{lccccc}
\hline & \multicolumn{2}{c}{ Municipal waste water drain receiving hospital waste water } & \multicolumn{2}{c}{ Ravi river } \\
\hline Hospital & Mean conc. & Before mixing & After mixing & Upstream to city & Downstream to city \\
\hline Mayo & 27.25 & $0.26 \mathrm{c} \pm 0.07$ & $0.85 \mathrm{~b} \pm 0.06$ & & \multirow{2}{*}{ ND* } \\
Services & 30.55 & $0.43 \mathrm{a} \pm 0.03$ & $1.29 \mathrm{a} \pm 0.18$ & 0.067 \\
Jinnah & 10.69 & $0.33 \mathrm{~b} \pm 0.03$ & $0.54 \mathrm{c} \pm 0.06$ & & \\
\hline
\end{tabular}

$* \mathrm{ND}=$ not detected.

\section{EXPERIMENTAL}

Analytical grade chemicals and reagents were used throughout the experiment. In first step, composite wastewater samples were collected from three teaching hospitals (Mayo, Services and Jinnah). Secondly wastewater samples were collected from municipal wastewater drains receiving the hospitals sewage. At last, river water samples were also collected both from upstream and downstream of the city. All the water samples were taken in $4 \mathrm{~L}$ amber glass bottles and transfer to laboratory at $4{ }^{\circ} \mathrm{C}$ by using ice box. Before analysis of the samples $1 \mathrm{~g} \mathrm{Na}_{2}$ EDTA was added, mixed well and stored at $4{ }^{\circ} \mathrm{C}$ but not more than $12 \mathrm{~h}^{12,13}$. The samples were concentrated by using solid phase extraction process. Before start of the extraction process, $2 \mathrm{~mL}$ methanol followed by $2 \mathrm{~mL}$ deionized water was used to activate the cartages. After that, samples were passed through the cartages. The targeted compound was extracted by using $2 \mathrm{~mL}$ methanol. The extracted samples were analyzed on HPLC (High performance liquid chromatography) by using reverse phase analytical column (RP-18e $250 \mathrm{~mm} \times$ $4.6 \mathrm{~mm}, 5 \mu \mathrm{m}$, manufactured by Merck) at room temperature and the flow rate was $0.8 \mathrm{~mL} / \mathrm{min}^{14,15}$.

Bacterial sampling and analysis: For bacterial sampling, sterilized amber glass bottles were used and size of each sample was $4 \mathrm{~L}$. About $2.5 \mathrm{~cm}$ of sampling bottles were kept empty for the shaking of samples. The samples were transport to laboratory in ice boxes and processed on same day. When every same day process was not possible, the samples were stored at $4{ }^{\circ} \mathrm{C}$ but not more than 2 days ${ }^{16}$. Identification and isolation of $S$. typhi was carried out by using Brilliance Salmonella agar by incubating at $37{ }^{\circ} \mathrm{C}$ for $24 \mathrm{~h}^{17}$. Co-culture of ofloxacin resistant $S$. typhi and ofloxacin sensitive E. coli was prepared in 1:1 ratio by using nutrient broth. Haemocytometer was used to prepare same inoculum size of each isolate ${ }^{18}$ and separately transfer to each antibiotic treatment prepared in iso-sensitest broth. The cultures were incubated at $37{ }^{\circ} \mathrm{C}$ for $24 \mathrm{~h}$. Cell density was measured after 0 and $24 \mathrm{~h}$ at $600 \mathrm{~nm}^{19}$.

\section{RESULTS AND DISCUSSION}

The antibiotic under study was detected from wastewater samples collected from all the three hospitals, but concentration of the antibiotic was not same in the wastewaters (Table-1). Concentration of ofloxacin in Mayo, Services and Jinnah was $21.25,30.55$ and $10.69 \mu \mathrm{g} \mathrm{mL}{ }^{-1}$, respectively. The difference in concentration was mainly due to different usage of antibiotic, number and type of patients, liking and disliking of physicians ${ }^{20}$. No wastewater treatment facility was available in the three hospitals. After mixing of hospital wastewater, an increase in concentration of the antibiotic in municipal wastewater was observed. This increase was mainly due to large intake of antibiotics from the hospitals ${ }^{21}$. Therefore, hospitals must be remembered as vital contributor of different pharmaceutical compounds like antibiotics ${ }^{22}$.

In Ravi river upstream to the city, ofloxacin was not detected while downstream to the city ofloxacin was detected viz. $0.067 \mu \mathrm{g} \mathrm{mL}{ }^{-1}$. Source of antibiotics in rivers are treated or untreated municipal wastewater. Therefore, pharmaceutical compounds usually detected from downstream to urban areas and not from upstream, but concentration depends up on amount of antibiotic received and dilution capacity of a river ${ }^{8,23,24}$.

As given in Table-2, river water upstream to the city before mixing first municipal wastewater drain were not contaminated with S. typhi. On the other hand, the samples collected downstream to first municipal wastewater drain were contaminated with the bacteria. The upstream samples were not contaminated because source of pathogenic bacteria in rivers are wastewater drains from urban areas ${ }^{25}$. All the samples collected downstream to municipal wastewater drains were contaminated with $S$. typhi. This is because, point sources are responsible for contamination of rivers with antibiotic resistant bacteria $^{26,27}$. These bacteria and antibiotics can reach to human through contaminated drinking water and through food due to plant and animal accumulation, respectively $y^{4,28}$.

TABLE-2

BACTERIA ISOLATED FROM DIFFERENT SITES OF RAVI RIVER

\begin{tabular}{lccc}
\hline Sampling sites & Bacteria & Status & Resistant (\%) \\
\hline Ravi siphon & & - & - \\
Upstream to first MWW drain & S. typhi & - & - \\
Downstream to first MWW drain & & + & $33 \%$ \\
\hline MWW = Municipal waste water & & &
\end{tabular}

Resistance level of $S$. typhi isolated from hospital wastewater, municipal wastewater and from the river water was measured at concentration below and above the $\mathrm{MIC}_{90}$ of ofloxacin. The result of the experiment revealed $50 \%$ of hospital wastewater isolates were able to survive at concentrations higher than $\mathrm{MIC}_{90}$ of ofloxacin (Fig. 1). On the other hand, in case of municipal wastewater isolates, $16.7 \%$ were found resistant to the compound (Fig. 2). The results of the study clearly indicate that hospitals isolates were more resistant to ofloxacin as compare to municipal wastewater isolates. This may be due to the fact that patients with severe infection usually hospitalized. As in early studies, it was concluded that hospitals are source of more resistant bacteria as compare to municipal wastewater because of selective type of patients ${ }^{29-31}$.

When the river isolates exposed to similar concentrations of ofloxacin, it was noted that $100 \%$ were able to survive at concentration higher than $\mathrm{MIC}_{90}$ of ofloxacin (Fig. 3). Previous 


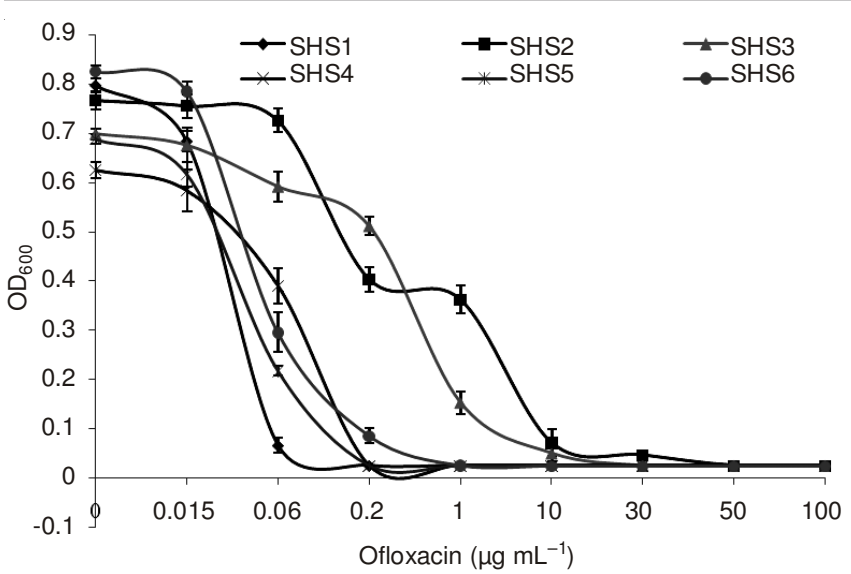

Fig. 1. Effect of ofloxacin on cell growth of $S$. typhi isolated from hospital wastewater

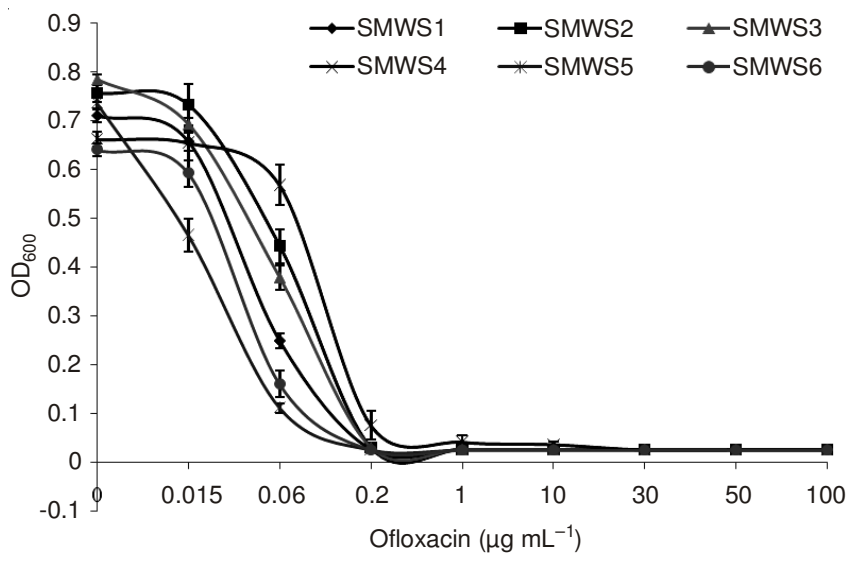

Fig. 2. Effect of ofloxacin on cell growth of $S$. typhi isolated from municipal wastewater

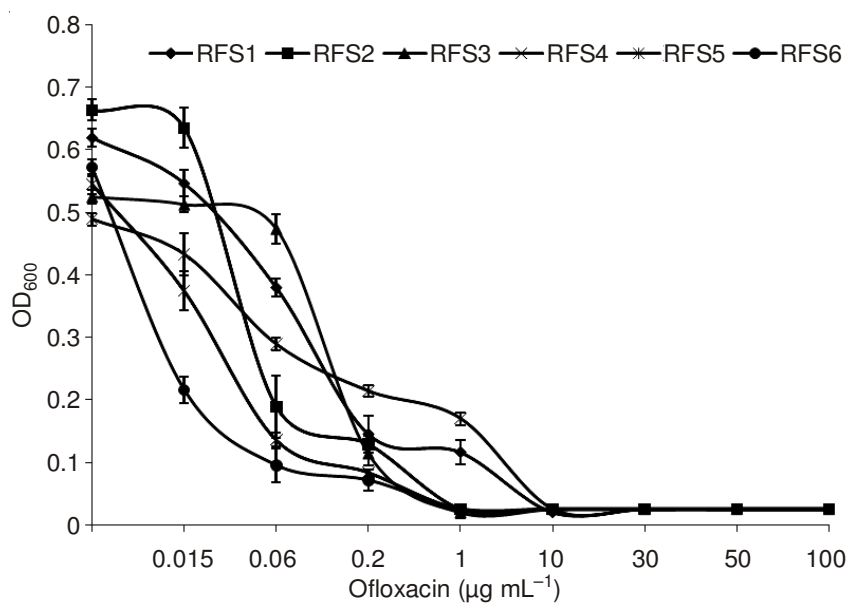

Fig. 3. Effect of ofloxacin on cell growth of S. typhi isolated from Ravi river downstream to Hudiara drain

studies reported that river isolated from downstream to point sources were 90 to $100 \%$ resistant to fluoroquinolones ${ }^{32,33}$. Most of clinical isolates of $S$. typhi were resistant to frequently using antibiotic including fluoroquinolones ${ }^{34}$. Many S. typhi isolates which were sensitive to fluoroquinolones are now resistant to the antibiotics ${ }^{35}$. Bacteria gain antibiotic resistance when exposed to the compounds for longer period of time $\mathrm{e}^{36}$ and through horizontal transfer by the transfer of plasmids ${ }^{37}$.
Transfer of antibiotic resistance between bacteria of two different species was studied by developing co-culture of antibiotic resistant and resistance $S$. typhi and E. coli, respectively. After $24 \mathrm{~h}$ of co-culture when the sensitive of $E$. coli was analyzed, it was found that $20 \%$ of isolates were resistant to ofloxacin. So it can be stated that antibiotic resistance characteristics can transfer among two different species of bacteria $^{38}$. Transfer of antibiotic resistance between two different species of bacteria can also occur in river water ${ }^{39}$.

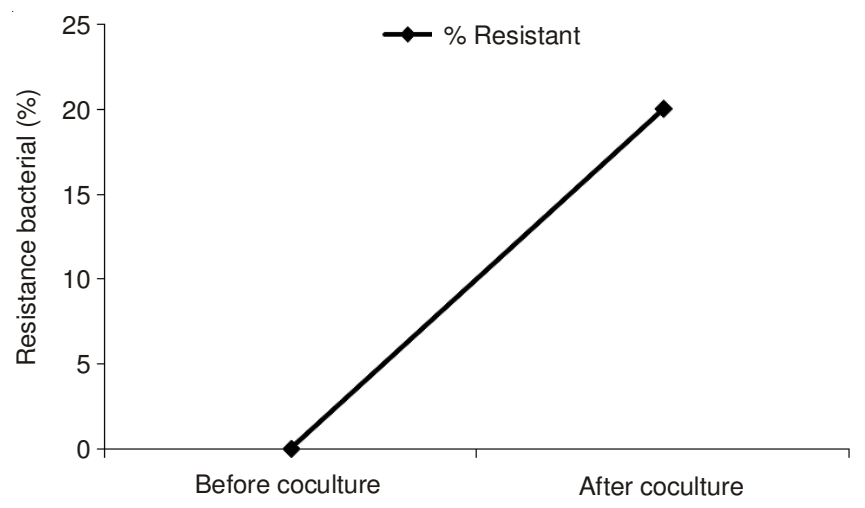

Fig. 4. Transfer of antibiotic resistance after coculture

\section{Conclusion}

It was concluded that river water was not contaminated with the antibiotic and antibiotic resistance bacteria upstream to the city before the introduction of first municipal wastewater drain. Untreated hospital and municipal wastewaters are responsible for dissemination of antibiotics and antibiotic resistant bacteria in the rivers. Concentrations of the antibiotics are increasing in river because of continuous input from hospitals and municipal wastewaters. Antibiotic resistance is also increasing in the aquatic environment due to contamination of antibiotics and horizontal transfer among different species.

\section{ACKNOWLEDGEMENTS}

This research article is part of Ph.D. thesis of principal author. The authors are thankful to Government College University, Lahore for providing funds and necessary facilities for the research work.

\section{REFERENCES}

1. K. Kummerer, Chemosphere, 75, 417 (2009).

2. S.K. Khetan and T.J. Collins, Chem. Rev., 107, 2319 (2007).

3. M. Ahmad, A.U. Khan, A. Wahid, A. S. Ali and F. Ahmad, Pak. J. Sci., 65, 10 (2013).

4. W. Li, Y. Shi, L. Gao, J. Liu and Y. Cai, Chemosphere, 89, 1307 (2012).

5. A. Sapkota, A.R. Sapkota, M. Kucharski, J. Burke, S. McKenzie, P. Walker and R. Lawrence, Environ. Int., 34, 1215 (2008).

6. P. Verlicchi, M. Al Aukidy, A. Galletti, M. Petrovic and D. Barceló, Sci. Total Environ., 430, 109 (2012).

7. L. Gao, Y. Shi, W. Li, H. Niu, J. Liu and Y. Cai, Chemosphere, 86, 665 (2012).

8. L.J. Zhou, G.G. Ying, J.L. Zhao, J.F. Yang, L. Wang, B. Yang and S. Liu, Environ. Pollut., 159, 1877 (2011).

9. F. Baquero, J.L. Martinez and R. Canton, Curr. Opin. Biotechnol., 19, 260 (2008)

10. F.C. Cabello, Environ. Microbiol., 8, 1137 (2006)

11. R. Schmieder and R. Edwards, Future Microbiol., 7, 73 (2012). 
12. B. Shao, D. Chen, J. Zhang, Y. Wu and C. Sun, J. Chromatogr. A, 1216, 8312 (2009).

13. X. Chang, M.T. Meyer, X. Liu, Q. Zhao, H. Chen, J. Chen, Z. Qiu, L. Yang, J. Cao and W. Shu, Environ. Pollut., 158, 1444 (2010).

14. . R. Lindberg, P.A. Jarnheimer, B. Olsen, M. Johansson and M. Tysklind, Chemosphere, 57, 1479 (2004)

15. M. Seifrtova, L. Novakova, C. Lino, A. Pena and P. Solich, Anal. Chim. Acta, 649, 158 (2009)

16. D. Li, T. Yu, Y. Zhang, M. Yang, Z. Li, M. Liu and R. Qi, Appl. Environ. Microbiol., 76, 3444 (2010).

17. A. Luczkiewicz, K. Jankowska, S. Fudala-Ksiazek and K. OlanczukNeyman, Water Res., 44, 5089. (2010).

18. Z.A. Butt, I. Haq and M.A. Qadeer, Pak. J. Botany, 43, 1053 (2011)

19. S. Roychoudhury, E.C. Catrenich, E.J. Mcintosh, H.D. Mckeever, K.M. Makin, P.M. Koenigs and B. Ledoussal, Antimicrob. Agents Chemother. 45, 1115 (2001).

20. C. Ort, M.G. Lawrence, J. Reungoat, G. Eaglesham, S. Carter and J. Keller, Water Res., 44, 605 (2010).

21. S. Suarez, J.M. Lema and F. Omil, Bioresour. Technol., 100, 2138 (2009).

22. K. Kummerer, Chemosphere, 45, 957 (2001).

23. W.H. Xu, G. Zhang, S.C. Zou, Z.H. Ling, G.L. Wang and W. Yan, Water Environ. Res., 81, 248 (2009).

24. L. Jiang, X. Hu, D. Yin, H. Zhang and Z. Yu, Chemosphere, 82, 822 (2011)
25. P. Servais and J. Passerat, Sci. Total Environ., 408, 365 (2009).

26. T. Garcia-Armisen and P. Servais, J. Environ. Manage., 82, 512 (2007).

27. J.J. Huang, H.Y. Hu, S.Q. Lu, Y. Li, F. Tang, Y. Lu and B. Wei, Environ. Int., 42, 31 (2012).

28. A. Azizullah, M.N.K. Khattak, P. Richter and D.P. Hader, Environ. Int., 37, 479 (2011).

29. T. Prado, W.C. Pereira, D.M. Silva, L.M. Seki, A.P.D. Carvalho and M.D. Asensi, Lett. Appl. Microbiol., 46, 136 (2008).

30. N. Rosenblatt-Farrell, Environ. Health Persp., 117, 16 (2009).

31. D.B. Fuentefria, A.E. Ferreira and G. Corçao, J. Environ. Manage., 92 , 250 (2011)

32. H. Dhanji, N.M. Murphy, C. Akhigbe, M. Doumith, R. Hope, D.M. Livermore and N. Woodford, J. Antimicrob. Chemother, 66, 512 (2011).

33. B.B. Pal, H.K. Khuntia, S.K. Samal, S.K. Kar and B. Patnaik, Int. J. Infect. Dis., 14, 384 (2010).

34. K. Molbak, D.L. Baggesen, F.M. Aarestrup, J.M. Ebbesen, J. Engberg, K. Frydendahl, P. Gerner-Smidt, A.M. Petersen and H.C. Wegener, $N$. Engl. J. Med., 341, 1420 (1999).

35. E.Y. Furuya and F.D. Lowy, Nature Rev. Microbiol., 4, 36 (2006).

36. L.Y. Hsu, T.Y. Tan, V.H. Tam, A. Kwa, D.A. Fisher and T.H. Koh, Antimicrob. Agents Chemother, 54, 1173 (2010).

37. J. Davison, Plasmid, 42, 73 (1999).

38. H. Kruse and H. Sorum, Appl. Environ. Microbiol., 11, 4015 (1994).

39. G.A. Osman, H.M. Hassan and M.M. Kamel, J. Am. Sci., 7, 1033 (2011). 